\title{
DÜRRENMATT: A PATOLOGIA DO PODER E A OPÇÃO PELA COMÉDIA
}

\author{
Paulo Astor Soethe *
}

\section{Introdução}

A pós a leitura das peças Der Besuch der alten Dame (A visita da velha senhora) e Die Physiker (Os físicos) ${ }^{2}$, de Friedrich Dürrenmatt, resta ao leitor, além da certeza de estar diante de grandes obras da dramaturgia em língua alemã, uma sensação de vazio e estranhamento. As peças contudo, não são o que se possa chamar uma representação apocalíptica e trágica de nosso mundo. Ao contrário, são "comédias" - conforme designação do próprio autor - capazes de provocar o riso durante sua apresentação, ao retratar enredos bastante acessíveis, mesmo familiares ao leitor/espectador de nosso tempo, habituado à representaçāo de intrigas de familia, vinganças, assassinatos, chantagens, paixões

* Universidade Federal do Paraná

1 DORRENMATT, Friedrich. Der Besuch der alten Dame. Zurique: Diogenes, 1980. Para as citaçōes, utilizaremos como base a traduçāo de Mário da Silva, (Editora Agir, 1963). sob o titulo $A$ visita da velha senhom. Pequenas alteraçôes feitas à tradução buscam maior adequação ao original em sua versão definitiva, de 1980.

$2 \quad$ lbid. Die Physiker. Zurique: Diogenes, 1980. Em português, sob o titulo Os fisicos, hả uma boa tradução de João Marchner (Editora Brasiliense, 1960), igualmente utilizada como base para as citações. 
c outros lugares comuns das relações humanas no mundo contemporàneo. Face a essa aparente incongruência é que a presente reflexão procurará compreender a tensão entre a pretensa alegria expressa pelo riso c a consciência melancólica que, como veremos, manipula a forma cômica.

$\mathrm{Na}$ tentativa de refletir sobre a natureza paradoxal desses textos, recorreremos às considerações do próprio Dürrenmatt sobre a natureza do cómico, aos estudos de Walter Benjamin sobre a alegoria em seu texto Ursprung des deutschen Truuerspiels (Origem do drama barroco alemão) ${ }^{3}$ e aos de Henri Bergson, em $O$ riso. Essa fundamentação teórica nos possibilitará refletir sobre o procedimento formal de construção da personagem Claire Zachanassian (Der Besuch der alten Dame, qual scja a manipulaçāo alegórica de motivos caracteristicos da sociedade de consumo. Em seguida, serão tecidos alguns comentários referentes à personagem Fräulein Doktor von Zahnd (Die Physiker), a fim de evidenciarmos semelhanças entre ela e Claire Zachanassian e chegarmos entāo a algumas conclusōes acerca da representação do poder na obra do dramaturgo suiço.

\section{A comédia como gênero possivel}

Em seu texto Theaterprobleme, ${ }^{5}$ Dürrenmatt toma clara sua opçio pela comédia: No mundo contemporaneo não há mais heróis trágicos, pois estão diluidas as noçōes absolutas de culpa, inocéncia, arrependimento, etc. Estabeleceu-se o caos e a representação do poder não pode mais ser feita $\mathrm{cm}$ termos absolutos. O Estado perdeu sua forma harmonica, e a fisica transformou o mundo em uma série de fórmulas matemáticas. Ele só pode agora ser representado por meio de estatisticas. O desalio do artista, face a isso, parece ser dar fonna concreta, representação visivel ao mundo e às relaçōes de poder que o caracterizam. Esse poder, contudo, só é visivel integralmente no momento de sua explosão, de sua fragmentação, como ocorte com a

3 BENJAMIN, Walter. Ursprung des deutschen Trauerspiels. Frankfun am Main: Suhrkamp. 1972. Para as citaçōes utilizamos a traduçāo de Sérgio Paulo Rouanct, Origem do drama barroco alemōo. São Paulo: Brasiliense. 1987. Vez por outra nos referiremos a obra como "Trauerspielbuch".

4 BERGSON, Henri. O riso. Ensaio sobre a significaçäo do cómico. Rio de Jauciro: Zahar, 1983.

5 DORRENMATT. Friedrich. Theater. Exsays und Reden. Zurique: Diogenes, 1980. p. 31-72. As traduçöes apresentadas nas citaçēes säo de nosia propria responsabilidade. 
bomba atômica, que funde genocidio e beleza ao explodir e formar o cogumelo. Assim:

(...) a missão da arte - se admitimos que ela de fato pode ter uma missão -, e por consequêencia a missão da dramaturgia dos dias de hoje é criar formas, conceber coisas concretas. É sobretudo a comédia que se mostra adequada a tal desafio. A comédia pressupõe um mundo ainda informe, um mundo em transformação, concebido como em processo de mudança radical. (...) o cômico consiste em dar forma ao informe, em configurar aquilo que é caótico. ${ }^{6}$

Ao aproximar elementos dispares c aparentemente desconexos é que a comédia preserva certa distância entre o público espectador e a realidade representada.

A dramaturgia dos materiais existentes é suplantada pela dramaturgia dos materiais criados pela imaginação. No riso manifesta-se a liberdade do ser humano; no choro, as suas necessidades. Nós hoje devemos dar mostras da liberdade. ${ }^{7}$

Note-se, então, que o caráter composicional orientado pela junção de elementos fragmentários, dispares e visualmente representados, frutos da livre criação do artista, é que determina, para Dürrenmatt, a vantagem da comédia frente a outras formas literárias. Tal caracterização é fundamental para termos claras as relações entre a comédia dürrenmattiana e a composição alegórica segundo Walter Benjamin, de que falaremos mais adiante.

Ao descartar a possibilidade de se escrever tragédias nos moldes clássicos, Dürrenmatt não nega a representaçāo do trágico. Este pode fazer-se presente através da comédia, surgindo nela como um momento terrivel, um abismo que se abre repentinamente.

Com isso se cstaria próximo à conclusão de que a comédia é a expressão do desespero; essa conclusão, porém, não é definitiva. Certamente, quem vê a falta de sentido e a ausência de esperança nesse mundo pode desesperar-se, mas o desespero não é a consequêencia única desse mundo, e sim uma resposta que se pode dar a ele. Uma outra resposta seria o nảo-desespero, a

6 DORRENMATT, Friedrich. Theater. Essays und Reden. Zurique: Diogenes, 1980. p. $60-1$.

Ibid., p. 68. 
decisāo, talvez, de sair-se bem diante do mundo (...) Também mantém disància aquele que quer avaliar seu oponente, aquele que se prontifica a lutar com ele ou livrar-se de seu ataque. Continua sendo possivel mostrar o homem de coragem. ${ }^{8}$

Ora, nesta decisāo de buscar representar o "homem de coragem" através do cômico, confluem a consciência da realidade que poderia conduzir ao desespero - o componente de amargor presente no riso - e a manutenção de uma postura consciente e critica, de resistencia diante da realidade. O riso, reportando-nos ao estudo clássico de Henri Bergson sobre esse assunto, "é o ponto em que convivem o mecânico e o vivo, como em uma encruzilhada." $"$ Ou seja, o riso funde a consciência do mecânico (daquilo que não é humano, daquilo que reifica o homem) e do vivo (a postura de resistencia crítica diante da reificação). É desta forma que o cômico alcança seu caráter paradoxal, eventualmente subversivo em relaçãio à ordem estabelecida. A representação trágica que surge em determinados momentos, os vazios que Dürrenmatt comparou a abismos, sāo por isso manifestações "redentoras" da realidade representada. Por um procedimento que é desde o início assumido como reação ao "mundo que conduziu ao grotesco, assim como à bomba atòmica", ${ }^{0}$ Dürrenmatt debruça-se sobre a realidade como o alegorista que busca no exercício de representação a redenção incerta para o mundo representado.

\section{O procedimento alegórico e a representação cômica do mundo}

Bergson menciona em $O$ riso "uma lógica da imaginação quie não é a lógica da razão", presente nas manifestaçōes do cômico. Esta lógica estariat próxima à do sonho, mas

nào o sonho deixado ao capricho da fantasia individual, mas sonhado por toda a sociedade. Para reconstitui-la, impöe-se um esforço de gèncro peculiar, pela qual se removerá a crosta exterior de juizos bem empilhados, e de idéias solidamente assentadas, para ver fluir bem no fundo de si mesmo, como um

8 DORRENMATT, Friedrich. Theater. Essays und Reden. Zurique: Diogenes, 1980. p. 62-3.

9 BERGSON, op. cir.,p. 27.

10 DORRENMATT., Theater, p. 62. 
lençol de água subterràneo, certa continuidade fluida de imagens que se interpenetram. Essa interpenetração não se dá ao acaso, mas obedece a leis, ou antes a hábitos, que estào para a imaginaçāo como a lógica está para o pensamento. "

Vindo de encontro ao caráter composicional da representação cómica, que procuramos destacar no item anterior, Bergson também aponta para a "remoção de uma crosta exterior de idéias solidamente aceitas", cm benefício da percepção de imagens que fluem e se interpenetram. O rearranjo das imagens da realidade, que pressupõe uma desmontagem de sua ordem anterior, respeitaria a já mencionada "lógica da imaginação".

Walter Benjamin, ao formular seu pensamento e propor uma nova forma de leitura da realidade, adequada a uma possivel concepção modema do mundo, vai operar com uma lógica semelhante em sua proposição básica: das fontes surrealistas apropria-se de técnicas de composiçāo textual próximas ao mecanismo dos sonhos, as quais vêm aliar-se a suas reflexões sobre o procedimento alegórico, iniciadas já a partir do "Trauerspielbuch". Também para Walter Benjamin, a composiçāo e o rearranjo de imagens fragmentárias da realidade possibilitaria uma compreensão mais legítima do mundo e mais adequada à dinâmica multifacetada, da qual o pensamento lógico linear não pode mais dar conta.

Ainda que Benjamin tenha desenvolvido as idéias a seguir partindo da análise especifica de "Trauerspicle" (dramas barrocos), as reflexões sobre a alegoria assumem um caráter mais abrangente já no "Trauerspielbuch" $\mathrm{c}$ incorporam-se a seu pensamento posterior. A predisposição alegórica passa a estar presente em seu próprio procedimento de análise da realidade, como recurso técnico, e continua a surgir tambím enquanto objeto, como ocorre na análise da obra de Baudelaire.

Na terceira parte do "Trauerspielbuch", intitulada Allegorie und Trauerspiel, Benjamin vai se propor a resgatar a alegoria como forma de expressão, opondo-se ao conceito romántico ainda em voga, segundo o qual ela não passaria de forma de ilustração. Este posicionamento contrário à alegoria estaria baseado na valorização do símbolo como procedimento poético autêntico. A concepção de símbolo, porém, tal como se apresenta nos textos teóricos a partir do Romantismo, nāo passaria, para Benjamin, de uma deturpação do símbolo teológico autêntico. A unidade do clemento sensivel e supra-sensivel que caracterizaria este último teria sido deformada numa relação entre manifestação e esséncia. Com isso, o mundo da ética

BERGSON, op cit., p. 29. 
seria imanente ao mundo do belo, o que diluiria o individuo e sua complexidade no sujeito ético idealizado. Ou seja, a arte estaria dissociada na vida e de suas relaçōes dialéticas, como manifestaçōes de uma esséncia pré-existente e desvinculada da realidade social e humana.

Benjamin vê na alegoria muito mais que um simples procedimento de significação - ela guardaria em seus abismos, no reaproveitamento de intenções malogradas de expressāo, toda a dialética do tempo histórico, revelando a "facies hippocratica" da história. Por isso, por utilizar-se de formas vencidas, e portanto mortificadas na dināmica dos conflitos sociais, a alegoria seria a exposiçāo da história como história mundial do sofrimento.

Ao utilizar-se de imagens da natureza e do mundo social, a alegoria mostra uma dupla face: ela é simultaneamente convenção (pois os signos pré-existem ao alegorista, que lhes atribui uma significação determinada) c expressão (pois cria novas realidades pela significação). Assemelha-se nisso à escrita hieroglifica, em que cada um dos signos possui um significado independente, além daquele que está em função do todo. Por isso, também a alegoria expressa pela palavra escrita assume um cariter eminentemente imagético, visual. Em cada fragmento desta escrita está encerrado um elemento da natureza (como objeto descontextualizado) que é simultancamente um elemento da história. Dai a comparação dos fragmentos alegóricos a nuínas, que tèm em si uma existência intrínseca, mas que são também fragmentos da história. Disso decorre a importancia, na produção ale góricia, de se evidenciar a construção do todo, já que cada elemento guarda em si também um significado. "Sem ao menos uma compreensão intuitiva da vida do detalhe através da estrutura, a inclinação pelo belo é um devancio vazio." 12

Consciente deste caráter composicional da representação alegórica e operando propositadamente com elementos da história mundial do solrimento, o alegorista identifica-se com o melancólico. Seu único divertimento é a alegoria e seu verdadeiro patrimonio consiste na experiéncia da unidade entre os sonhos e signilicaçōes, ja que na alegoria a voz mortificada permanece viva, a utopia concretiza-se pela significação. Através da mençấo ao luto, Benjamin explicita a relaçāo entre procedimento alegórico t at "ponderação sobre sinais e sobre o futuro", caracteristica dos lutuosos. A sensação de perla de um centro organizador para a própria vida é o lato que desencadcia o luto enquanto operaçāo de reorganização dos elementos que ainda estão à disposição, sendo o principal deles a própria morte. Assim, 
toda imagem escrita de que o alegorista pode fazer uso é parte de um texto mais amplo que busca reencontrar um novo centro para a ação de significar. Ele procede desta forma "ad infinitum", compondo e recompondo imagens existentes. Sua ação não está voltada para a verdade obtida através da meditação, mas para a verdade que está nos próprios objetos da significação. As transformações e o reordenamento destes objetos é que constituem sua ocupação.

Ele a assume porque ć deste procedimento que pode resultar a redenção de sua subjetividade: esta última, que havia transformado tudo em objetos de signifição, descobre-se por isso mesmo repentinamente só. Os objetos em si, como frutos da subjetividade, negam a existência do próprio mal que podem conter, já que são meras significações. A subjetividade, porém, não se submete à mesma negação, porque, ao contrário, encontra seu ser ao descobrir-se como realidade última. "Na visão de mundo da alcgoria, a perspectiva subjetiva está portanto incluida na economia do todo." ${ }^{13} \mathrm{~A}$ descoberta desta supremacia da subjetividade torna o alegorista capaz mesmo de fazer do processo de composição alegórica um objeto a mais a ser manipulado pela significação. Com isso a subjetividade passaria a excreer dominio sobre a consciência de si mesma, e possibilitaria, pela manipulação das formas de significação, o surgimento de momentos de redençäo, podendo indicar "ao luto o momento de entrar em cena, e de sair". ${ }^{4}$

Da mesma forma que Dürrenmatt vè na composição de comédias a possibilidade de representação do "homem de coragem", que desafĩa o desespero ante a "ordem perdida do mundo"("verlorene Weltordnung"). 15 Benjamin encontra na prática do alegorista um caminho para a redenção da subjetividade perdida, uma possibilidade de que o processo de luto chegue a bom termo e possibilite a recuperação frente à morte (que se alcance a "ressurreiçāo", em termos teológicos). Tanto para um como para o outro, é somente a obtenção de formas concretas a partir do reaproveitamento de fragmentos da realidade que possibilita esta significação redentora.

As personagens Claire e von Zahnd são na obra de Dürrenmatt exemplos desse anseio por subjugar através da alegoria o que ameaça 0 humano e sua liberdade.

13 BENJAMIN, op. cit., p. $25 \%$.

it lbid., p. 258 .

is DORRENMATT., Mheater, p. 63. 


\section{Claire Zachanasian ou o culto do consumo: simulacros para a compensação do absurdo do poder.}

Uma pequena cidade falida, Güllen, aguarda o regresso daquela qü lhe pode representar a salvação: prepara-se com o melhor de suas tradiçoes, as autoriclades todas presentes, discursos, homenagens. Ha anos a jovem Klara Wäscher abandonava a cidade, humilhada, grávida de seu namorado Ill Alfred, que negara a paternidade da criança através de um arranjo com colegas, para permanecer solteiro e poder realizar um casamento mais rentável, já em vista. Ela se tornou uma prostituta, acabou por se casar com milionários dos quais herdou fortunas e transformou-se em uma mulher poderosissima. Regressa agora, muitos anos mais tarde, como Claire Zachanassian, e todos esperam conseguir dela ajuda financeira para o reerguimento da cidade. Ela se mostra disposta a colaborar com uma quantia estrondosa, mas exige em troca que se faça justiça: Ill deveria ser morto por um dos habitantes da cidade para que ela pudesse ter sua vingança. Em uma primeira reação a cidade nega-se a aceitar tal proposta, mas ja ficam patentes todos os indicios de que a vida de Ill não duraria muito. Ele se revolta, implora por sua vida aos moradores e a Claire, contudo as contingèncias são mais fortes: após uma tentativa frustrada de fuga, Ill acaba por aceitar seu destino. Como pretexto ć forjada a fundação de uma associaçào para o desenvolvimento da cidade, à qual Claire laz uma vuluosa doação. Logo apos a cerimoniat, Ill $\mathrm{e}$ assissinado pelos moradores da cidade e seu corpo levado por Claire. A cidade canta em coro, ao fim da peça, lestejando a conquista de recursoss para a recuperaçăo economica c a consequiente melhora no nivel de vida de seus habitantes.

Com esta breve retomada do enredo, podemos passar as consideraçōes sobre o significado amplo que assume a ligura de Claire Zachanassian em Der Besuch der alten Dame, comédia publicada pela primeira vez em 1956. Ha no texto indicios claros de que Claire com seu dinheiro exeree poder não só sobre Güllen, mas também sobre estruturas sociais mais amplas. Recebe e dispensa no decorter da peça autoridades internacionais, a imprensil, chefes de instituiçöes financeiras poderosas. Seu poder sobre a vida e a morte estende-se não só sobre a existencia de Ill, mas tambem sobre a de outras pessoas, sobre as quais Claire parece ter dominio absoluto - basta pensionos em seus criados, guarda-costas e maridos. Ela mesma, porem, a despeito deste poder, apresenta-se como um figura languida, indiferente é sem vida. 
No decorrer da peça vamos nos dando conta de que a caracterização dessa figura controversa se dá através do arranjo de fragmentos, ora mercadorias, artigos de luxo e próteses para o corpo, ora pessoas robotizadas que a servem incondicionalmente, quase como extensões dela mesma, ora recordaçōes de sua juventude. Esses fragmentos passam a assumir uma intenção significativa clara, à medida que revelam o caráter grotesco e desumanizado da velha senhora e surgem como ruinas de sentimentos do passado, transformadas agora em desejo de vingança. É esse desejo que impulsiona o exercício do poder, e toda a ostentação que acompanha o cortejo de objetos somente faz demonstrar o domínio de Claire sobre o destino das pessoas.

Sua indiferença e superioridade frente às outras personagens ficam patentes desde o início, pois ela dá pouca importância aos esforços dos moradores de Güllen em ajudá-la ou influenciar suas atitudes. Eles, na verdade, não têm qualquer poder de ação sobre ela. Mesmo antes de explicitados os planos de vingança de Claire, já há vários indícios do teor de suas pretençōes, principalmente pelas perguntas da visitante aos moradores, nas quais se menciona sempre o tratamento que seria dispensado a alguém que fosse condenado à morte na cidade. Também o professor local, com suas referéncias clássicas, afirma que Claire deveria na verdade chamar-se Cloto, reportando-se à Parca que manipula os fios da vida na mitologia grega.

À medida que o dinheiro e o poder de Claire, objetos de fascínio da população de Güllen, se impõem de forma definitiva, a visitante cada vez mais assume um caráter paradoxal - seus simbolos de ostentação acabam por revelar a degeneração de seus sentimentos. Também sua aparência física contrapõe-se ao luxo e à riqueza que a cercam.

Quanto a esse último aspecto Claire se esforça por desfazer as idealizações de III, que pretendia com seu antigo amor atrair as graças da visitante em benefício da cidade. Ela faz questão de enfatizar o seu envelhecimento e também o fato de que seu corpo é constituído por próteses:

ILL: Mas vocè não mudou nada, minha bruxinha.

CLAIRE ZACHANASSIAN: Qual nada. Eu também fiquei velha e gorda. E a minha pema esquerda lá se foi. Um acidente de automóvel... Mas esta pema mecânica é perfeita, nāo acha? [Levanta a saia c mostra a pema esquerda.] ${ }^{16}$ 
E mais adiante em outro momento de investida romântica:

ILL: Tivesse o tempo parado, minha bruxinha. Pudesse a vida nāo nos ter dividido.

CLAIRE ZACHANASSLAN: E isso o que vocè deseja?

ILL: Sim, isso, só isso. Porque eu amo voce. [Beija-lhe a mão dircita.] A mesma mão, branca e fresca.

CLAIRE: Engano. Também é mecanica. De marfim.

ILL [larga a mão dela horrorizado]: Clara, será que tudo em vocè são próleses?

CLAIRE: Quase. Fơ uma queda de aviāo no Afeganistāo. Sai rastejando do meio dos destroços, única sobrevivente. De mim, ninguém dả cabo. ${ }^{17}$

A composição de seu corpo por partes que não passam de simulacros de vida, a ênfase dada ao sintético e ao artificial apontam para a ausência de inteireza e autenticidade na figura de Claire. Dilacerada por seus sentimentos fracassados, ela vive em função da justificativa de um passado que não se pode mais resgatar. Seu próprio nome revela essa dimensão de si mesma: a composição Zachanassian a partir de Zacharoff, Onassis e Gulbenkian, explicada por Dürrenmatt em apéndice à obra ${ }^{18}$, pode ser entendida como fruto da reorganizaçāo aleatória de fragmentos de sua vida, além de estabelecer forte contraste com o "Wäscher" ("lavadeiro") que trazia de solteira. Essa inadequação entre passado e presente revela-se também pelo afrancesamento de "Klara": o nome do passado é maquiado pela ostentaçĩo do gosto burguês, mas torna-se apenas simulacro incapaz de alcançar a superação do que busca esconder.

A expressão do dilaceramento, contudo, não assume qualquer tom de apelo à compaixão do público. Pelo contrário, é exatamente por força desse dilaceramento que Claire é uma figura cômica. Estabelece-se entre seu drama pessoal e o leitor/espectador uma relaçāo de distância - em conformidade com a posiçāo de Dürrenmatt sobre a opção pela comédia, que desenvolvemos na segunda parte deste artigo. A distảncia, como já dissemos, é alcançada pela junção de elementos dispares. A indiferença e a frieza de Claire diante do destino de Ill opōem-se à dramaticidade de seu passado, do mesmo modo que sua figura grotesca afasta-se do luxo e ostentação que carrega consigo. 
Dessa forma, fundem-se o elemento mecânico, desumanizado, e o componente vital, presentificado pela carga de sentimentalidade e paixōes que a trama traz em si, na forma de ecos do passado. Estabelece-se o paradoxo entre as intenções de reparação pelos sentimentos perdidos na juventude e o total afastamento dos vínculos de sentimentalidade que dariam sentido a esse desejo de reparação. Claire é a representação concreta do vazio, cuja forma, pelo vazio que representa, possibilita a expressão do paradoxo - a "encruzilhada" de Bergson. Dai sua expressão estar mais adequada ao cômico.

O olhar cômico e a percep̧ão melancólica do mundo aproximam-se. Através da representaçāo da história pessoal de Claire, põe-se em questāo a própria dinâmica do poder, e portanto também a dinâmica da história dos homens. É possível aproximarmos seu caráter desumanizado e grotesco à caveira barroca, à já mencionada "facies hippocratica" da história, de que fala Walter Benjamin. Nela se exprime tudo que desde o início é prematuro, sofrido e malogrado: no caso de Claire, os traços desse rosto impassível são marcados pela impossibilidade de obter de fato, através do excrcício do -poder, a reparação pelos sofrimentos do passado, dada a inexorabilidade do tempo. Benjamin:

E porque não existe [na caveira] nenhuma liberdade simbólica de expressão, nenhuma harmonia clássica da forma, em suma, nada de humano, essa figura, de todas a mais sujeita à natureza, exprime nāo somente a existéncia humana $\mathrm{cm}$ geral, mas, de modo altamente expressivo, e sob a forma de um enigma a história biográfica de um individuo. Nisso consiste o cerne da visão alegórica: a exposição barroca, mundana, da história como história mundial do sofrimento, significativa apenas nos episódios do declinio. Quanto maior a significação, tanto maior a sujeição à monte, porque ć a morte que grava mais profundamente a tortuosa linha de demarcação entre a "physis" e a significação. ${ }^{19}$

Por sua constituiçāo fragmentária c artificial, desumanizada, Claire Zachanassian encarna em si a figura da ostentação da sociedade moderna, que conduz à morte e a exige como oferta. Claire exerce seu poder sobre Güllen objetivando apenas, em última instância, a morte de 111 . $\mathrm{O}$ assassinato, contudo, ultrapassa um sentido restrito para assumir o caráter de sacrifício ritual, onde o que importa é scu potencial de significação. A velha

BENJAMIN, op. cit., p. 188. 
senhora manipula a população de Güllen, seus criados e o próprio lll como signos que devem presentificar a reparação que ela busca, na tentativa cega de compensar o passado. O maior indício dessa intençāo compensatória pode ser encontrado se analisarmos o motivo da pantera negra, que percorte o texto em seus momentos decisivos.

Quando a bagagem de Claire é descarregada pelos criados, desfilando num cortejo de ostentaçāo de sua riqueza e causando a admiração dos moradores locais, passam adiante dos olhos do espectador/leitor alguns objetos que causam certa estranheza: junto com as muitas malas, sāo descarregados uma jaula e um caixão. Na jaula encontra-se a pantera negra.

Através da relação com alguns detalhes do primeiro diálogo entre Claire e Ill, o leitor mais atento já é capaz de interpretar a presença do exótico animal:

CLAIRE: Chame-me como vocè sempre me chamou.

ILL: Meu gatinho-do-mato.

CLAIRE [ronronando como um velho gato]: E que mais?

ILL: Minha bruxinha .

CLAIRE: E eu o chamava de minha pantera negra .

ILL: Ainda sou.

CLAIRE: Bobagem. Vocè engordou. Ficou velho e com cara de pau-d'agua. ${ }^{20}$

A pantera negra é alegoria do próprio III, que Claire vai manipular ao gosto de sua vontade. Neste primeiro momento, percebe-se a recusa da visitante a ceder à retomada pura e simples do passado. A realidade presente nega a idealizaçäo a que faz tender o apelido carinhoso.

No segundo ato ocorre uma fuga providencial da pantera c toda a cidade, de maneira oportuna, sai à caça do animal. A essa altura Claire já havia feito sua proposta de trocar a morte de Ill pelas doaçōes em dinheiro. A situação, portanto, seria perfeita para que ocorresse um disparo "acidental" e Ill fosse morto. Sob essa ameaça e pressentindo que os moradores deixavam-se encantar pela proposta da velha senhora, apesar da aparente recusa, Ill torna explicita a alegoria, ao queixar-se para o policial da cidade que não quer dar importancia a suas reclamaçōes:

O POLJCIAL: Homem, nāo tenho tempo para ficar discutindo as suas idéias fixas. Preciso ir. A maluca da milionaria 
deixou fugir seu gatinho de estimaçāo. A pant era negra.

Eu preciso caçá-la. Toda a cidade precisa caçá-la.

[Sai pelo fundo.]

ILL: E a mim que estão caçando, a mim. ${ }^{21}$

Páginas adiante, a pantera é morta, Claire é avisada e pede então que um de seus criados passe a tocar uma marcha fúnebre. $O$ professor chega em seguida e oferece em sinal de luto um canto executado pelo coral que o acompanhava. O clima de luto e morte é instaurado de forma cômica, pela inadequação das reaçōes em torno da morte do animal. As reaçōes de Ill, porém, fogem a essa inadequação, pelo fato de cle perceber o que realmente se passa na cidade. Desesperado, cle ainda procura por Claire e suplica a ela que poupe sua vida retirando a oferta. Ela porém se recusa $\mathrm{e}$ faz um relato dos fatos do passado que constituem o crime pelo qual ele deverá pagar. A cena encerra-se com o anúncio de dois criados de Claire: "A pantera negra está morta, a pantera negra está morta." 22

Após o retardamento da execução de Ill, que ocorre no terceiro ato, finalmente sucede-se a catástrofe. Claire aproxima-se então do corpo de seu antigo amor e ordena que o tragam para ela. Olha-o longamente e diz: "Está outra vez. como era há muito tempo, a minha pantera negra." ${ }^{23}$

De posse do corpo morto de III, Claire deixa a cidade sob os louvores da população, que assume a funçāo do coral da tragédia grega. Ela leva consigo a única recompensa pelo passado amargo: um cadáver. Pela morte Claire póde reaver seu antigo amor, transformado agora $\mathrm{em}$ objeto através da arbitrariedade da significação. Assumindo a conotação da vítima sacrificial, Ill é reificado e pode ser manipulado pela vontade de Claire. O epíteto .carinhoso passa a ser sinal de mortc. Para reconquistar sua "pantera negra" a "bruxinha" opera sua magia e seduz pelo poder do consumo os moradores de Güllen.

Da mesma forma que opera alegoricamente com o destino das pessoas, Claire também constitui-se uma alegoria do poder. As consequiencias da história biográlica individual, que constituem o fato central da peça, explicitam temas caros à sociedade contemporânea. Afinal, que elemento move a constituição das grandes estruturas de poder nos dias de hoje? Que preço é preciso pagar pelo sonho do desenvolvimento cconómico, pela melhoria das condições de vida? Como se opera a sedução

21 DORRENMATT., A visita... p. 97.

22 Ibid., p. 112.

23 Ibid., p. 185. 
pela mercadoria? A oferta de. Claire aos moradores de Güllen esvazia-se de sentido e põe-se em função de uma causa absurda, reflexo da ruína dos valores e também das frustraçōes de sua vida pessoal. O poder se fortalece alimentando-se de sua própria falta de sentido.

Claire leva de Güllen apenas um simulacro como reparação. Revela assim o vazio que a impulsionou ao ato de significação, expondo sua própria existência como vazia de sentido. Rendida à morte, Claire $\dot{e}$ aquilo que significa, ativa e passivamente: um simulacro erigido à condição de centro organizador da existência e da ação. O poder exercido em função da criação das necessidades de consumo sacrifica suas oferendas à morte, mas evidencia por esse sacrifício suas próprias brechas - não conquista nada além da alegoria de seu vazjo: a negaçāo da vida, a conquista do corpo morto.

A representação das personagens em coro, na cena final da peça, explicita a transposição dos valores de Claire para o seio da cidade de Güllen. Ela agora surge $\mathrm{cm}$ cena como uma estátua de pedra representando uma divindade pagã, seguida de seu cortejo e do caixāo que leva o corpo de 111. O canto entoado é uma louvação ao bom padrão de vida, mas a contradição e o paradoxo presentes nessa louvação já se evidenciam nos primeiros versos:

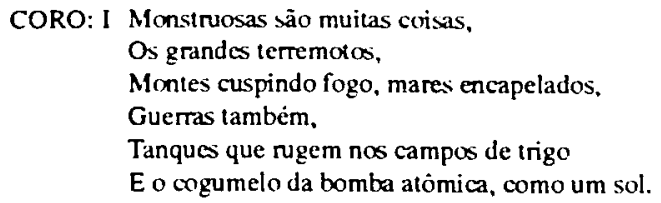

CORO II: Mas nada mais monstruoso

Do que a pobreza:

Não sabe aventuras.

Sufoca a desolada humanidade

Nas malhas monótonas

De um dia vazio após dias vazios. ${ }^{24}$

Não ć a vida que está em jogo, mas sim evitar a pobreza. Afirmar em seu credo que a pobreza é menos terrivel que a explosão da bomba atômica é para a população de Güllen negar a vida em favor do consumo. Apesar da monstruosidade dessa postura, que encontra em Ill a sua vítima, a representação cómica é que assegura, como possibilidade formal, a reação de 
Dürrenmatt a essa realidade. O entrecruzamento do caminho trágico da vida de $\mathrm{Il}$ com a moldura cômica em que a ação se desenvolve mantém explícita a intenção crítica do texto. Paralelamente, manifesta-se também a percepção melancólica do mundo através da prática interminável do alegorista que organiza e reorganiza os fragmentos da realidade, sem encontrar para eles centro organizador capaz de lhes atribuir sentido.

Claire Zachanassian é fruto dessa construção que opera com os fragmentos da sociedade contemporânea. Construída como personagem, passa ela também a ser fragmento e em outras obras posteriores de Dürrenmatt. Como representação do poder em sua dimensão mais decaída, é possivel encontrar, a nosso ver, ecos dessa personagem também em Fräulein Doktor von Zahnd, de Die Physiker. É sobre ela que passaremos a tecer algumas considerações.

\section{Mathilde von Zahnd ou A patologia do poder e o saber científico}

Procuraremos nesta parte final do artigo apontar determinadas semelhanças entre Claire Zachanassian e a personagem central da comédia Die Physiker, também de autoria de Friedrich Dürrenmatt, c publicada pela primeira vez em 1962. Não nos interessará aqui refletir sobre as diferenças formais entre as duas peças em questão, pois isso mereceria por si só um estudo específico. Iremos nos ater sim às caracteristicas das personagens mencionadas e seu significado, pressupondo já suficientemente desenvolvidas as reflexões sobre a denominação "comédia", atribuida a ambos os textos.

Die Physiker envolve o destino de três internos de um hospício. Dois deles foram recolhidos por assumirem cada qual a personalidade de um físico famoso, Einstein e Newton, e o terceiro, de fato físico proeminente, por afirmar manter conversaçāo com o rei Salomão, que lhe transmitiria mensagens.

O sanatório "les Cerisicrs", onde estāo internados, tem em Fräulein Doktor Mathilde von Zahnd sua administradora e psiquiatra chefe. Ela controla o tratamento de seus pacientes e afirma conhecê-los muito bem: "... conheço-os melhor do que eles próprios." ${ }^{25}$

25 DORRENMATT., Os fisicos, p. 19. 
Quando os très físicos começam a causar problemas, assassinando cada qual a enfermeira responsável por seu tratamento, ela evita que sof ram as sançōes cabiveis a qualquer cidadão comum, justificando suas atitudes como conseqüëncias do seu desequilibrio mental.

Os três assassinatos são a chave para o desenvolvimento da trama. Na verdade, o louco que recebe as mensagens de Salomão, Johann Wilhelm Möbius, havia se recolhido voluntariamente ao sanatório para impedir que suas descobertas cientificas acabassem se tornando públicas, pois seu poder de destruiçāo poria em risco a própria existência da humanidade. $O$ falso Newton, por sua vez, é também de fato um físico renomado, Alec Jasper Kilton, agente secreto a serviço de uma grande potência, e que portanto tambem simulara a loucura para poder internar-se no hospicio. Sua missão é levar Möbius por bem ou por mal ao país que o enviou, para que o poderio decorrente de suas descobertas esteja à disposiçāo do governo local e não caia cm mãos inimigas. As mãos inimigas, contudo, já haviam manipulado também o seu fantoche: o falso Einstein, na verdade o famoso físico Joseph Eisler, desempenha a mesma missāo que seu colega de sanatório, só que em favor da potencia inimiga. Ambos revelam suas verdadeiras identidades a Möbius e os très falam sobre seus crimes. O envolvimento afetivo com as enfermeiras, que se haviam apaixonado por eles, havia-as levado a tomarem conhecimento dos respectivos planos. Para que não fossem malogradas as intençōes de cada um dos físicos e seus segredos fossem mantidos, havia se tornado necessário eliminar as enfermeiras, apesar do amor que realmente existia.

Quando as verdadeiras identidades são reveladas, estabelece-se uma situaçāo de tensāo entre os dois agentes inimigos, e tudo leva a crer que um será eliminado pelo outro. Uma intervenção conciliatória de Möbius, entretanto, logra fazer que ambos abdiquem de suas intençós anteriores c se disponham a permanecer para sempre no sanatório, voltando a agir corro loucos, para preservarem assim seus segredos e com isso o bem da humanidade. Cada um se recolhe a seu quarto, o palco esvazia-se e a peça parece por alguns momentos ter chegado a bom fim:

NEWTON: Transformemo-nos novamente em loucos. Andemis como o fantasma de Newton.

EINSTEIN: Tixpuemos de novo como Kreisler e Beethoven.

MOBIUS: Deixemoi que Salomào apareça.

NEWTON: Loucos, porém satrios.

EINSTEIN: Presos, porim lives.

MÖBIUS: Fisicos, porim inocentes. 
[Os três acenam um ao outro e vāo a seus quartos. Da direita entram McArthur e Murillo. Vestem agora uniformes negros, com boné e pistolas. Arrumam a mesa. McArthur empurra para fora, pela direita, o carrinho com louça usada: Murillo coloca a mesa redonda diante da janela à direita e sobre ela as cadeiras viradas, assim como se faz num restaurante. O salão fica de novo vazio (...). $!^{26}$

Note-se na indicaçāo de cena acima como são enfatizados os sinais de que a peça teria chegado ao fim. Após as falas aparentemente definitivas dos três físicos, que parecem soar como mensagem final da peça, os dois seguranças do sanatório entram e arrumam o palco como quem fecha um bar ou restaurante. Os móveis retirados de cena e os dois seguranças saem pela direita, no sentido da linha de um texto que chega ao fim, e o palco fica pela segunda vez vazio.

A indicação de cena, porém, ainda continua:

[(...) Depois aparece da direita a $\mathrm{sr}^{2} \mathrm{dn}$ Mathilde von Zahnd. Como sempre de guarda-pó branco. Estetoscópio. Olha ao redor de si. Finalmente entra Sievers, também de uniforme preto. $]^{27}$

A figura da psiquiatra, que surgira até então com certa discrição na peça, volta ao palco para alterar o rumo dos acontecimentos de forma decisiva. O texto segue:

\section{ENFERMEIRO-CHEFE: Pat roa. DOUTORA: Sievers, o quadro.}

[McArthur e Murillo trazem um grande retrato, emoldurado com pesada moldura de ouro, representando um general. Sievers retira o velho retrato da parede e pendura o novo quadro. $\left.\right|^{28}$

A partir dai desmascara-se também a verdadeira figura da diretora do sanatório. O quadro do general, que substitui o do pai de Fräulein Doktor von Zahnd, mencionado no primeiro ato, é indício de sua ligação com o poder, que até então não havia sido manifestado na peça. A única indicação dessa característica da psiquiatra havia sido sua influência sobre a atuação

26 DURRENMATT., Os fisicos, p. 78-80.

27 lbid., p. 80.

28 Ibid., p. 80-1. 
das autoridades policiais, quando do assassinato das enfermeiras. $O$ inspetor responsável pelas investigaçōes, após ser dispensado por von Zahnd, comenta com Möbius:

\begin{abstract}
Achei très assassinos que nāo tenho de prender, sem que com isso fique com a consciència pesada. Pela primeira vez o direito está de férias. $\dot{E}$ um sentimento fabuloso. Pois que o direito, meu amigo, exige um grande esforço, a gente se deströi, a seu serviço, moral e fisicamente. Estou precisando de um descanso. ${ }^{29}$
\end{abstract}

Como Claire, von Zahnd também está acima do poder local institucionalizado e dita regras e leis.

Após o pseudo-encerramento da peça, em conversa com seus pacientes, a diretora do sanatório explica-lhes também ter recebido a visita do rei Salomāo, que a teria incumbido de levar a cabo a missão antes conferida a Möbius. Como este último havia falhado, ao internar-se no sanatório, caberia agora a ela tornar concreta a descoberta fatal do brilhante fisico.

Como Claire, ela também constrói uma grande fortuna, passa a manipular os destinos de seus pacientes e estende seu poder sobre uma parcela representativa de toda a humanidade. Os cientistas tentam alertá-la para o fato de estar doente, desequilibrada, já que a visāo do rei Salomāo nāo havia passado de uma invençāo de Möbius para poder esconder sua descoberta. Ela, porém, nāo lhes dá importância, afirma estarem mentindo e mostra-lhes como seria inútil tentarem impedi-la, já que seriam considerados loucos pela opiniāo pública. Os assassinatos que haviam cometido teriam servido para confirmar irremediavelmente a loucura de cada um. Também isso havia sido previsto e planejado por ela:

\footnotetext{
DOUTORA: Eu só me aproveitei de uma oportunidade. O saber de Salomão tinha que ser salvo e sua traição tinha que ser punida. Tive de tomá-los inócuos, por meio dos assassinatos. Eu lancei as trés enfermeiras para cima de vocés, ja contando com sua correspondéncia. Vocès foram dóceis como autómatos e mataram como carrascos. ${ }^{30}$
}

O paralelo com a manipulaçāo exercida sobre a população de Güllen por Claire é evidente. De posse dos manuscritos de Möbius, von Zahnd apenas aguarda $\mathrm{em}$ silèncio, até o momento de concretizar seus planos. As 
demais personagens comportam-se conforme o esperado, correspondendo aos caprichos da vontade de uma mulher amarga e ambiciosa. Igualmente, as causas de seu desequilíbrio e de sua ânsia pelo exercício do poder assemelha-se aos anseios de reparação pelas frustrações no caso de Claire. Na primeira aparição de Fräulein von Zahnd, o inspetor de polícia estava diante de um quadro, admirando-o. A psiquiatra entra e explica de quem se trata:

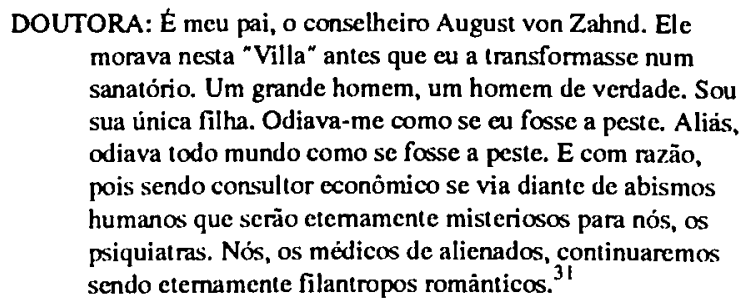

Apesar de ter sido odiada pelo pai, a psiquiatra diz admirá-lo como homem e como pessoa. Relaciona os abismos abertos em sua personalidade à prática da atividade cconômica e contrapōe essa crueza à filantropia romântica do psiquiatra. Esses pólos de tensão - admiração c ódio, filantropia e misantropia -são responsáveis pelas máscaras assumidas por Fräulein von Zahnd: ao fim da peça a prática médica não passa de um disfarce para a conquista do poder econômico ("Fundei fábricas, enormes, construi uma indústria atrás da outra, edificando um gigantesco truste ${ }^{\prime \prime 2}$ ) e a filantropia dả lugar à misantropia, pela conquista do poder de destruição que a invenção de Möbius proporciona.

A viagem de meia-idade - "corcunda" e "estéril", cm seu próprio dizer - sente-se escolhida pela figura viril de Salomão, fruto de sua insanidade. Ao mencionar novamente a figura do pai e substituir seu quadro pelo de um general, fica aberto o caminho para a interpretação de sua insanidade como änsia de compensação de suas frustrações de infância e juventude, nessa relação com a figura paterna:

Ele [Salomão], que possui milhares de mulheres, me escolheu. Agora tornar-me-ei mais poderosa do que meu pai. Meu truste há de reger paises, conquistar os continentes, explorar o sistema

31 DURRENMATT., Os fisicas... p. 17-8.

32 Ibid., 86. 
solar, ir à galáxia de Andrómeda. O resultado da comta foi exato: nảo em beneficio do mundo, mas em beneficio de uma virgem velha e corcunda. ${ }^{33}$ ) (nảo hả grifos no original)

Como no caso de Claire, a reparaçāo do passado ocorre de forma falseada, através do simulacro que representa o exercício do poder. Restam como saldo para Fräulein Doktor von Zahnd as mortes das enfermeiras, o aniquilamento das identidades reais dos físicos e ainda todo o poderio de destruiçāo que a invençāo de Möbius oferece. Após afirmar que a conta está ajustada, von Zahnd se retira para dar continuidade a seus planos: "Vamos embora, Sievers. O conselho diretor está esperando. Inicia-se um empreendimento mundial, a produçāo começa." ${ }^{3+}$

Impotentes diante da situação, os três físicos encerram a comédia voltando-se ao público. Kilton e Eisler assumem novamente as identidades de Newton e Einstein, e Möbius apresenta-se por último, como Salomão. Em sua fala enfatiza-se o declínio e a destruição da riqueza do rei bíblico como consequiencias de sua sabedoria, a qual o havia afastado de Deus e esfacelado seu temor a Ele. É a figura do rei decrépito, que reina sobre cidades mortas, sobre terra radioativa e vazia de sentido, tal qual ele mesmo a descreve. Seu poder é o centro da ação insana da senhora louca. No centro, o vazio e o declinio, e ao seu redor, como simulacros, o poder e a morte.

A sabedoria salomónica, como representante do saber científico, $\dot{\mathfrak{e}}$ vítima da queda quando posta a serviço da ànsia desenfreada de poder. $O$ avanço cientifico, que acarreta além das conquistas também conseqüências funestas, é posto em questão da mesma forma que o consumo o havia sido em Der Besuch der alten Dame. Estes dois mitos da modemidade tornam-se objetos de crítica, e com eles a dinàmica e a essència do poder no mundo contemporáneo.

O poder, para isso, é representado através do paradoxo $\mathrm{e} \mathrm{em} \mathrm{seu}$ componente de insanidade. Através das protagonistas das duas peças, ele paira sobre as autoridades locais, sobre as instituições civis e mesmo sobre os representantes das grandes potencias. Elas assumem, como figuras literírias, o caráter amplo que possibilita ao dramaturgo a construção da forma necessíria para refletir sobre o problema. Tanto Claire como Mathilde von Zahnd encerram $\mathrm{cm}$ si o clemento vital, ja pelo fato de serem mulheres, mas esse elemento se degenera pela intervenção das culpas individuais do passado, atribuidas a figuras masculinas. O pai de von Zahnde Ill Alfred são

33 DORRENMTATT., Os fricos... p. 87-8.

3. Ibid., p. 88. 
os responsáveis pelas frustrações em virtude das quais as poderosas senhoras exercem seu poder ilimitado. E também os três físicos, guardadas as devidas diferenças, selam seus destinos e se tornam incapazes de reagir contra o poder de von Zahnd ao assassinarem as enfermeiras. O elemento vital, a fertilidade, o amor desinteressado surgem como possibilidades nas figuras femininas, mas são frustrados pela determinação cega das personagens masculinas: do administrador financeiro, do aldeão que quer arrumar para si um casamento rentável, dos cientistas que colocam seus planos acima de qualquer coisa.

Assim, o poder é desmascarado alegoricamente em seu caráter de degeneração e corrupção por interesses meramente econômicos, que se superpõem à própria vida. $\mathrm{O}$ amor como centro organizador da existência humana, aquilo que poderia atribuir sentido à vida dos homens e suas relaçōes, é substituído pelo objeto morto, pelo elemento artificial e patológico. O exercício do poder no mundo contemporâneo encontra seu paralelo somente na atitude obsessiva de uma velha senhora que vive $\mathrm{em}$ funçāo dos frutos de seu desequilibrio e das frustraçōes de seu passado. Frustrações pelas utopias sepultadas com os horrores da guerra e com a reorganização das sociedades sobre bases tão desumanas quanto as anteriormente vigentes.

Nas peças de Dürrenmatt o vazio e a inconformidade permanecem, mas transformados em objetos passiveis de crítica e reação. Pudemos, neste exercício de leitura, transformar o produto artístico da percepção melancólica das estruturas de poder em objeto de reflexão e crítica sobre os textos. Estivemos, como foi dito, diante de grandes obras da dramaturgia em língua alemã. Obras de um autor de nosso tempo, que ainda nos permite acreditar na possibilidade do reencontro deste centro organizador apresentado sempre como ausente, mas que justamente por isso constituiu-se no objeto mais instigante de nossa reflexão, mesmo em seus silêncios.

\section{RESUMO}

O presente estudo procura demonstrar de que forma a construção das personagens femininas centrais e a intençāo cómica das peças Der Besuch der alten Dame e Die Physiker, de Friedrich Dürtenmatt, estāo à serviço de uma visão crítica da sociedade contemporânea, sobretudo em relação à dinâmica do poder e à manipulação do saber científico. 